IZA DP No. 7238

Business, Bankruptcy, and Beliefs: The Financial Demise of NBA Stars

Ruby Henry

February 2013 


\title{
Business, Bankruptcy, and Beliefs: The Financial Demise of NBA Stars
}

\author{
Ruby Henry \\ Rutgers University \\ and IZA
}

\section{Discussion Paper No. 7238 \\ February 2013}

\author{
IZA \\ P.O. Box 7240 \\ 53072 Bonn \\ Germany \\ Phone: +49-228-3894-0 \\ Fax: +49-228-3894-180 \\ E-mail: iza@iza.org
}

Any opinions expressed here are those of the author(s) and not those of IZA. Research published in this series may include views on policy, but the institute itself takes no institutional policy positions. The IZA research network is committed to the IZA Guiding Principles of Research Integrity.

The Institute for the Study of Labor (IZA) in Bonn is a local and virtual international research center and a place of communication between science, politics and business. IZA is an independent nonprofit organization supported by Deutsche Post Foundation. The center is associated with the University of Bonn and offers a stimulating research environment through its international network, workshops and conferences, data service, project support, research visits and doctoral program. IZA engages in (i) original and internationally competitive research in all fields of labor economics, (ii) development of policy concepts, and (iii) dissemination of research results and concepts to the interested public.

IZA Discussion Papers often represent preliminary work and are circulated to encourage discussion. Citation of such a paper should account for its provisional character. A revised version may be available directly from the author. 


\section{ABSTRACT}

\section{Business, Bankruptcy, and Beliefs: The Financial Demise of NBA Stars*}

The financial troubles of professional athletes are an ongoing topic of intrigue. In general, the zealousness brought to private equity schemes are a common factor in observed financial insolvency. Considering the behavioral attribute of self-confidence I propose a simple model which explains entrepreneurial activity and adverse financial outcomes. The model implies that investment effort increases with self-confidence, while promoting financial solvency. Constructing a unique database of NBA players affords a singular opportunity to measure confidence directly from behavior, avoiding bias from self-reported surveys. In addition, I observe for-profit business ventures and use this data to test the model's implications for the outcomes of both entrepreneurial activity (investment effort) and bankruptcy. Without correcting for endogeneity it does appear that starting businesses causes bankruptcy. After using charitable foundations as an instrument, however, the data confirms the model's prediction - that investment effort is associated with financial solvency. That said, I also find that the effect of confidence on bankruptcy to be non-monotonic. Having some confidence decreases the probability of bankruptcy, but high levels increase this probability.

JEL Classification: D10, I20, J13

Keywords: self-confidence, bankruptcy, athletes, entrepreneurs influence, entrepreneurship

Corresponding author:

Ruby Henry

Department of Economics

Rutgers University

75 Hamilton Street

New Brunswick, NJ

USA

E-mail: rhenry@post.harvard.edu

\footnotetext{
* I thank Lawrence Jules, Greg Moore, Jennifer Hunt, Anne Piehl, John Landon-Lane, Roger Klein, Norman Swanson, Gilles Saint-Paul, Bernard Salanié, and seminar participants at IZA, Wesleyan and Rutgers.
} 


\section{Introduction}

The financial troubles of many professional athletes are well-documented. The exceedingly high incomes of these players make the phenomenon all the more interesting. For example, Vin Baker was the 8th pick in the 1993 National Basketball Association (NBA) draft and played for 13 years in the NBA which resulted in approximately $\$ 93$ million dollars in earnings. His Connecticut home was foreclosed in 2008 for approximately $\$ 2$ million dollars. Foreclosures are not the worst event, however. Consider Derrick Coleman who was the 1st pick in the 1990 Draft and played for 15 years in the NBA. His estimated career earnings are $\$ 87$ million. He filed for bankruptcy in 2010 .

A scientific examination of this phenomena was heretofore absent. I propose a simple model which explains adverse financial outcomes and test it on a unique hand-collected dataset of NBA athletes. Though the model is general to entrepreneurial activity, using this particular source of data allows me to observe personal characteristics as selfconfidence that would otherwise be unobserved or wrought with biases. Benabou and Tirole [2002] show that self-confidence increases the motivation to undertake tasks and that too much confidence can cause an individual to exert effort when it is optimal to abstain. With this in mind, I model the individual's probability of successful ventures as a function of investing effort and self-confidence. The model implies that the probability of solvency is increasing in effort. Furthermore it is increasing in self-confidence up to a point and then decreasing for very high levels of confidence. This is intuitive as a degree of self-confidence is needed to undertake investment, however too much confidence leads to nonoptimal behavior.

To test these implications, I use data from on-the-job behavior of these athletes. To be sure, their general task is to score points, however there are several approaches to completing this task in the form of 3 basic types of shots each with a distinct difficulty

level. I proxy self-confidence with attempts at the most difficult type of shot controlling for the actual observed ability to shoot these difficult shots, among other factors. 
Increasing this measure of self-confidence by 1 standard deviation, increases the number of entrepreneurial pursuits by .10. This is non-negligible considering that the average number of these pursuits is .37. These for-profit entrepreneurial pursuits are the empirical counterpart of effort in the model. To estimate the effect of effort and self-confidence on bankruptcy, I first address the endogeneity of effort. Imagine that one is facing a fall in earnings or other type of financial distress. A plausible course of action is to start investing in private equity ventures to generate future income. In this way, investment effort would be endogenous. To deal with this, I use charitable endeavors as an instrument for investment effort. Without the endogeneity correction, investment is positve predictor of bankruptcy. Correcting for the upward bias, however, yields a negative effect of investment on bankruptcy consistent with the model.

\section{A Theory of Individual Solvency ${ }^{1}$}

\subsection{Model}

Agents decide on a time allocation of (Leisure and Investment Effort). Their payoff is the sum of (1) present utility from leisure and (2) the utility of expected wealth.

\subsubsection{Perceived Probability of Financial Solvency}

An individual's perceived probability of solvency is $\tilde{\pi}_{i}$. It is a function of their selfconfidence, $\theta_{i} \in[0,1]$, which is known to them, and the effort they choose to put into investment $e_{i} \in[0,1]$.

$$
\tilde{\pi}_{i}=\theta_{i} e_{i}
$$

\footnotetext{
${ }^{1}$ Solvency means financial soundness, well-being, competence. The opposite of bankruptcy or financial distress.
} 
The equation above reflects that the probability of successful entrepreneurship increases with the effort made and with how able the agents view themselves to be. These two forces are complementary and strongly so. In this simplified model, if no effort is made, an individual will never believe they will succeed. Similarly if the individual has no self-confidence, success is unfathomable.

\subsubsection{Utility}

The present utility of an individual is:

$$
U\left(\lambda^{i}\right)
$$

where $\lambda^{i}$ is leisure time. Total time is normalized to 1 , thus $\lambda^{i}=1-e^{i}$.

The cost of effort, $\kappa(e)$, is utility from leisure:

$$
\kappa(e)=-U(1-e)
$$

I assume that the marginal cost of effort is positive,

$$
\kappa^{\prime}(e)=U^{\prime}(1-e)>0
$$

and increasing,

$$
\kappa^{\prime \prime}(e)=-U^{\prime \prime}(1-e)>0 \text {. }
$$

In addition to present utility, agents expect utility from wealth. If the individual remains solvent, they expect to keep wealth $W_{i}$. If the individual goes bankrupt they will lose their wealth.

For simplicity, the weights on present utility and the future utility are equal. 


\subsection{Choosing Effort Level}

Agents maximize expected utility

$$
E V_{i}=U\left(1-e_{i}\right)+\pi_{i} W_{i}
$$

subject to

$$
\tilde{\pi}_{i}=\theta_{i} e_{i}
$$

The F.O.C. is:

$$
-U^{\prime}\left(1-e_{i}\right)+\theta_{i} W_{i}=0
$$

Defining $\Psi=\left[U^{\prime}\right]^{-1}$, the optimal effort level is ${ }^{2}$ :

$$
e_{i}^{*}=1-\Psi\left[\theta_{i} W_{i}\right]
$$

\section{Implications for Effort and Perceived Success}

\section{Proposition 1}

(i) $\frac{\partial e_{i}^{*}}{\partial \theta}=-\Psi^{\prime}\left[\theta x W_{i}\right] x W_{i}>0$

The individual's investment effort is increasing in confidence. This is the complementarity between the factors from the individual's perception of the success probability.

\footnotetext{
${ }^{2}$ The assumption $\kappa^{\prime \prime}(e)>0$ implies $U^{\prime \prime}(\cdot)<0$, which ensures a maximum. $\Psi>0, \Psi^{\prime}<0$.
} 


\section{Proposition 2}

(i) The perceived probability of a successful venture: $\tilde{\pi}_{i}=\theta e_{i}^{*}$.

(ii) $\frac{\partial \pi_{i}}{\partial \theta}=\theta \frac{\partial e_{i}}{\partial \theta}+e_{i}>0$

When confidence increases, the perceived probability of success increases. This arises through the direct effect of $\theta$ on the perceived outcome probability and the indirect effect of $\theta$ increasing effort.

\section{Testing the Model's Implications}

Testing the implications above requires suitable measures of $e$ and $\theta$. I build a data base with 7 years of NBA draft data (1990-1996) including various personal and professional characteristics of the players. The data are a result of searches of public sources including Wikipedia, nba.com, and basketball-reference.com. Because of the high-profile of the individuals, there is a wealth of information available.

As mentioned above, NBA players are a group that lend themselves to this study. To understand the strengths and limitations, there are many myths about this group which are dispelled with basic tabulations. First, the NBA is actually a relatively small employer of professional athletes. As is commonly known, just 5 players are active on the court at a time and so even with non-starters, few teams carry more than 20 players per season. There are roughly 30 teams per season. Second, the typical NBA career is very short relative to a non-NBA career. For Round 1 players - the most talented - the average career is under 10 years for the 1990-1996 cohorts. Third, although historically most players completed college, this is no longer the case. Though almost $90 \%$ of the 1990 draft have 4 years of college, this fell to just under $40 \%$ by the 1996 draft. Fourth, not all players are making millions of dollars. Even in Round 1 salaries start in the $\$ 400$ thousands. 


\subsection{Effort}

The share of time dedicated to entrepreneurial pursuits (effort) is not observed. I proxy investment effort with the number of for-profit business ventures. Data on business ventures was obtained from the sources listed above and other key word internet searches. The average number of businesses is .378; roughly one-quarter of players in this cohort started a business venture. The raw correlation between the number of businesses and ever going broke is .51 with a $p$-value $=0.00$. The types of businesses vary, however the majority fall into the real estate and food service industries.

\subsection{Confidence}

Confidence is very difficult to measure and is subject to bias with self-reporting. Instead, I use self-confidence observed at work to proxy self-confidence in entrepreneurial pursuits. The idea is that the behavior in one income-generating activity is correlated with behavior in other income-generating activities. To capture self-confidence, I argue that if two people have equal ability, and 1 of them is more likely to undertake a task requiring that ability, then that person has higher self-confidence all else equal. Consider the diagram in Figure 1 and the labeled 3-point line. Shots taken outside this line are called 3-point shots and are considered the most difficult shots. These shots have the lowest success rate at $22.4 \%^{-}$ far lower than the success rates of 2-point shots and free throws which are $43.9 \%$ and $69.7 \%$ respectively. Specifically, I use the number of 3-pointer attempts per 36 minutes of playing time controlling for the observed ability to shoot 3-pointers (share of successful attempts). The confidence measure is from the player's rookie (first) year of playing to avoid endogeneity issues. 


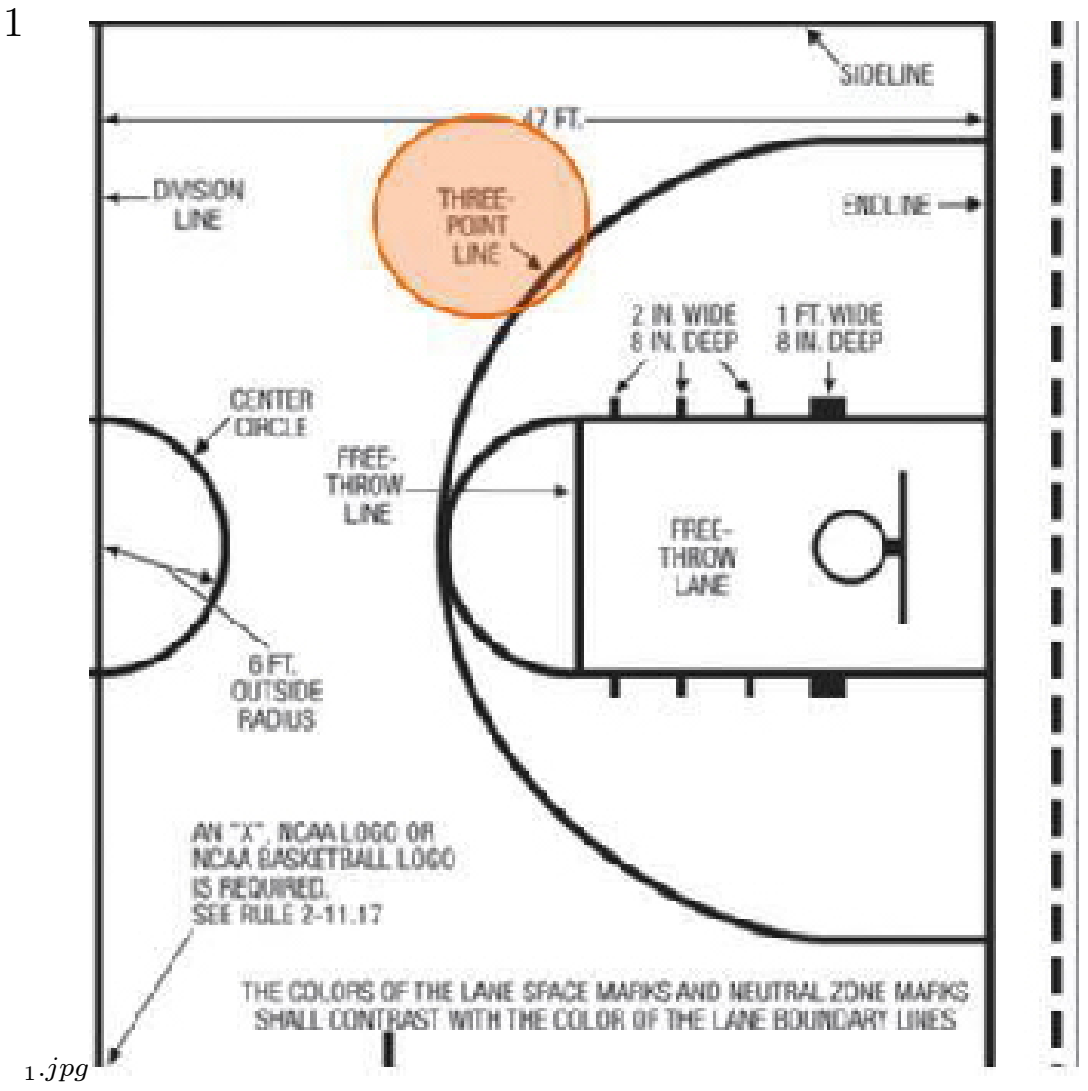




\subsection{Wealth Exemptions}

In previous research, Fan and White [2001] show that higher wealth exemptions from creditors also increase entrepreneurial activity. Just as tax exemptions decrease tax liability, bankruptcy wealth exemptions decrease asset pay out to creditors. Otherwise stated, the expected loss from entrepreneurial activity is smaller when there is less one can lose. In addition, the wealth exemption can directly affect the decision to file for bankruptcy. The level of the wealth exemption varies by state. For example, the state of the New York had a $\$ 150,000$ exemption, and Virginia had just a $\$ 5,000$ exemption.

\subsection{Endogeneity in Entrepreneurial Activity}

The data also show that 1 more business venture multiplies the odds of going broke by 3.5. It is quite possible that when an individual is in financial strain, he starts businesses as a rescue measure. As mentioned just above, NBA careers are short. From anecdotal evidence, careers are shorter than the players anticipate. The data show that careers typically end 1-2 seasons after the largest drop in salary and players appear to start businesses when they receive a strong signal about the market's declining valuation of their talent. Otherwise put, when it is clear that "the end is nigh" for earnings, players would rationally explore other options for income. In this case, those with financial problems would be more likely to start businesses foreseeing the end of their earnings.

This would mean the coefficient on entrepreneurial activity would exhibit a positive bias. To deal with this endogeneity I use a control function with the number of charitable foundations as the instrument. Clearly, financial lack does not cause charitable endeavors. At the same time, one can imagine that other traits would generate both nonprofit and forprofit endeavors.

In standard notation,

$$
y=\beta x+\varepsilon, \mathbb{E}(x \varepsilon) \neq 0,
$$


where $y$ represents bankruptcy and $x$ stands for entrepreneurial activity. I assume that the proposed instrument, $z$, satisfies $\mathbb{E}(z \varepsilon)=0$.

I can then represent the endogenous variable as

$$
x=\theta z+v,
$$

where $v$ is the part of $x$ that may be caused by $y$. I control for the endogeneity by introducing a predicted $\widehat{v}$ in the second stage.

\subsection{Specification}

Other controls include years of college, age at draft, position, and height.

Proposition 1 treated the relationship between investment effort and confidence. A individual's effort, $e_{i}$, is modeled as a linear function of confidence $q$ and the other control variables:

$$
e_{i}=\alpha q_{i}+\vec{\beta} \vec{w}_{i}+\varepsilon_{i}
$$

Implications for the perceived success probability presented in Proposition 2 can also be tested. $\tilde{\pi}_{i}$ is modeled as a function of $q$ and $e_{i}$ and other control variables:

$$
\tilde{\pi}_{i}=\gamma_{1} q_{i}+\gamma_{2} e_{i}+\vec{\eta} \vec{w}_{i}+\xi_{i}
$$

The effort variable, $e_{i}$, is equal to the number of forprofit businesses. $\widetilde{\pi}_{i}$ is equal to 1 if the individual has had a bankruptcy and/or a foreclosure. In the dataset $5 \%$ of the sample has had such an adverse event. The wealth exemption is entered in hundreds of thousands. 
Table 1: Summary Statistics

\begin{tabular}{l|l|l|l|l|l}
\hline & \multicolumn{1}{l}{ N } & \multicolumn{1}{l}{ Mean } & \multicolumn{1}{l}{ Std. Dev. } & Min & \multicolumn{1}{l}{ Max } \\
\hline Bankrupt/Broke & 190 & .047 & .212 & 0 & 1 \\
Number of For-Profit Businesses & 190 & .378 & 1.035 & 0 & 10 \\
\hline Number of Charities & 190 & .394 & .788 & 0 & 4 \\
3 Point Attempts & 189 & 1.43 & 1.84 & 0 & 9.1 \\
Success Share 3-Pointers & 189 & .224 & .195 & 0 & 1 \\
\hline Wealth Exemption (100Ks) & 174 & 2.57 & 3.68 & .15 & 10 \\
Years of College & 188 & 3.49 & .956 & 0 & 4 \\
\hline Draft Age & 190 & 22.11 & 1.13 & 18 & 26 \\
Height & 190 & 2.02 & .0928 & 1.78 & 2.29 \\
\hline Point Guard & 190 & .115 & .321 & 0 & 1 \\
\hline \hline
\end{tabular}




\subsection{Determinants of Investment Effort}

\section{Table 2: Dep. Var.: Number of For-Profit Businesses (OLS)}

\begin{tabular}{|c|c|c|c|c|c|c|c|}
\hline & (1) & (2) & (3) & (4) & (5) & (6) & (7) \\
\hline Confidence & **.111 & & **.124 & **.096 & $* .090$ & $* .083$ & $* .083$ \\
\hline (3-Point Tries) & . $(056)$ & & $(.048)$ & $(.046)$ & $(.051)$ & $(.050)$ & $(.050)$ \\
\hline \multirow[t]{2}{*}{ 3-Point Success } & & & -.222 & & -.101 & -.026 & -.023 \\
\hline & & & $(.312)$ & & $(.327)$ & $(.322)$ & $(.324)$ \\
\hline \multirow[t]{2}{*}{ Wealth Exemption } & & **.029 & & $* .025$ & $* .026$ & $* .029$ & $* .029$ \\
\hline & & $(.015)$ & & $(.015)$ & $(.016)$ & $(.016)$ & $(.016)$ \\
\hline Years of College & & & & & & -.071 & .069 \\
\hline & & & & & & $(.096)$ & $(.097)$ \\
\hline \multirow[t]{2}{*}{ Age at Draft } & & & & & & $* * *_{-} .207$ & $* * *-.205$ \\
\hline & & & & & & $(.076)$ & $(.077)$ \\
\hline \multirow[t]{2}{*}{ Point Guard } & & & & & & & -.022 \\
\hline & & & & & & & $(.184)$ \\
\hline Obs. & 188 & 173 & 188 & 173 & 173 & 171 & 171 \\
\hline $\mathrm{R}^{2}$ & .06 & .06 & .07 & .08 & .09 & .13 & .13 \\
\hline
\end{tabular}


Table 2 above gives some insight into the entrepreneurial activity of these individuals. The interpretation of the confidence measure is not exactly straightforward. Instead, increasing the confidence measure by 1 standard deviation is associated with a .10 increase in the number of businesses. As is consistent with previous literature the wealth exemption does seem to affect the number of business ventures. Increasing the wealth exemption by $\$ 100 \mathrm{~K}$ is associated with a .029 increase in the number of businesses. These associations are not exactly trivial as the average number of businesses was .378. The only other control that achieves significance is the age at first draft. It seems plausible that the younger one is at the draft the more likely to venture into entrepreneurial activity.

\subsection{Misperceiving the Drivers of Success}

The odds ratios are reported from the logit in Table 3. At first, investment effort appears to increase the probability of bankruptcy. Using the endogeneity correction gives the result that 1 more business reduces the odds of bankruptcy by a factor of 10 . This is a large magnitude though it is not significant. With respect to confidence, however, the data tell a very different story than the modeled perception of success. The individual's beliefs that confidence strictly increases (decreases) the likelihood of success (failure) is strongly contradicted by the data. In fact, a one standard deviation increase in confidence multiplies the odds of going broke by 3 . 
Table 3: Logit Model with Dep. Var.=1 if Broke (Odds Ratios)

\begin{tabular}{|c|c|c|c|c|c|c|}
\hline & (1) & $(2)$ & (3) & (4) & (5) IV & (6) IV \\
\hline $\begin{array}{l}\text { Investment Effort } \\
\text { \# of Businesses }\end{array}$ & $\begin{array}{c}* * * 4.487 \\
(2.233)\end{array}$ & & $\begin{array}{l}* * * 3.56 \\
(1.226)\end{array}$ & $\begin{array}{l}* * * 3.59 \\
(1.022)\end{array}$ & $\begin{array}{l}.059 \\
(.192)\end{array}$ & $\begin{array}{l}.091 \\
(.325)\end{array}$ \\
\hline $\begin{array}{l}\text { Confidence } \\
\text { (3-Point Tries) }\end{array}$ & & $\begin{array}{l}* * * 1.836 \\
(.429)\end{array}$ & $\begin{array}{l}* * * 2.477 \\
(.876)\end{array}$ & $\begin{array}{l}* * * 2.257 \\
(.866)\end{array}$ & $\begin{array}{l}* * * 3.02 \\
(.915)\end{array}$ & $\begin{array}{l}* * * 2.958 \\
(.915)\end{array}$ \\
\hline 3-Point Success & & $\begin{array}{l}.795 \\
(1.52)\end{array}$ & $\begin{array}{l}3.659 \\
(4.819)\end{array}$ & $\begin{array}{l}3.457 \\
(7.350)\end{array}$ & $\begin{array}{l}4.551 \\
(7.308)\end{array}$ & $\begin{array}{l}4.609 \\
(8.200)\end{array}$ \\
\hline Wealth Exemption & & & $\begin{array}{r}* * 1.91 \\
(.089)\end{array}$ & $\begin{array}{r}* * 1.219 \\
(.083)\end{array}$ & $\begin{array}{r}* * 1.38 \\
(.217) \\
\end{array}$ & $\begin{array}{r}* * 1.377 \\
(.202)\end{array}$ \\
\hline Years of College & & & $\begin{array}{c}.764 \\
(.441)\end{array}$ & $\begin{array}{c}.769 \\
(.412)\end{array}$ & $\begin{array}{l}1.045 \\
(.832)\end{array}$ & $\begin{array}{l}1.022 \\
(.777)\end{array}$ \\
\hline Age at Draft & & & $\begin{array}{l}1.077 \\
(.498)\end{array}$ & $\begin{array}{l}1.140 \\
(.491)\end{array}$ & $\begin{array}{c}.471 \\
(.412)\end{array}$ & $\begin{array}{c}.528 \\
(.491)\end{array}$ \\
\hline Point Guard & & & & $\begin{array}{l}1.290 \\
(.491)\end{array}$ & & $\begin{array}{c}1.970 \\
(2.622)\end{array}$ \\
\hline Obs. & 188 & 173 & 173 & 173 & 173 & 171 \\
\hline Pseudo $R^{2}$ & .31 & .39 & .55 & .56 & .55 & .57 \\
\hline
\end{tabular}

Note: Odds Ratios are reported. 
Indeed it seems that although previous research has argued that self-confidence is needed to undertake entrepreneurial tasks, self-confidence does not always promote the success of such tasks. Is there any point at which self-confidence can improve financial outcomes? Considering a different form for the probability of success lends some insight in Section 5. The new specifications are as follows:

$$
\begin{gathered}
e_{i}=\alpha_{1} q_{i}+\alpha_{2} q_{i}^{2}+\vec{\beta} \vec{w}_{i}+\varepsilon_{i} . \\
\pi_{i}=\gamma_{1} q_{i}+\gamma_{2} q_{i}^{2}+\gamma_{3} e_{i}+\vec{\eta} \vec{w}_{i}+\xi_{i} .
\end{gathered}
$$

\section{Effort and Solvency are Nonmonotonic in Confi- dence}

Changing the specification in this manner produces far more intuitive results. First, consider the effect of confidence on effort in Table 4. The data reveal an inverted U-shape relationship. Let's call the inflection point $\bar{\theta}$. Below $\bar{\theta}$ effort is increasing in confidence. With some complementarity between effort and confidence this is intuitive. For levels of confidence above $\bar{\theta}$, effort is decreasing in confidence. This may seem strange at first. Imagine that on odd days an individual wakes up with very high self-confidence, convinced that success is inevitable in any task undertaken. On even days, however, the individual arises with very low self-confidence (relative to $\bar{\theta}$ ). When the individual feels more confident, it is rational to make less effort as the confidence is overstated. When the individual feels low confidence, it is rational to exert relatively more effort, because the failure is not as real as it seems.

Because the confidence measure and its square are very highly correlated, I also construct an identical confidence measure from the last amateur year of playing. I include the square of this measure in the columns labeled with "Lag" as a replacement for the con- 
fidence measure of the rookie year. The results remain quite consistent. Using Column (6), I find that increasing the confidence measure from the 25 th percentile to the median, increases the number of businesses by .34. Increasing the measure from the median to the 75 th percentile increases the number of businesses by .13. Again, the average number of businesses is .378 .

As before, correcting for the endogeneity of investment effort in the bankruptcy equation gives the correct sign: additional businesses reduce the odds of bankruptcy. Note that the odd ratios are reported for interpretation, and so a ratio less than 1 corresponds to a negative coefficient. From Column (6), increasing the number of for-profit businesses by 1 would be associated with a 2.86 decrease in the odds of bankruptcy. Table 5 also shows a consistent U-shape relationship between confidence and bankruptcy. Even holding effort constant this intuitive as a certain amount of confidence is needed to succeed, but too much confidence can lead to poor choices. 
Table 4: Dep. Var.: Number of For Profit Businesses (OLS)

\begin{tabular}{|c|c|c|c|c|c|c|}
\hline & (1) & (2) Lag & (3) & (4) Lag & (5) & (6)Lag \\
\hline Confidence & $* .218$ & $* * * .182$ & $* * .273$ & ***.192 & .237 & $* * .145$ \\
\hline (3-Point Tries) & $(.130)$ & $(.062)$ & $(.142)$ & $(.067)$ & $(.149)$ & $(.070)$ \\
\hline Confidence $^{2}$ & -.025 & $* * *_{-} .012$ & -.035 & $* * *_{-} .011$ & -.035 & $* *_{-} .011$ \\
\hline$\left(3\right.$-Point Tries $\left.{ }^{2}\right)$ & $(.030)$ & $(.004)$ & .032 & $(.004)$ & $(.032)$ & $(.005)$ \\
\hline \multirow[t]{2}{*}{ 3-Point Success } & & & -.322 & -.209 & -.111 & .074 \\
\hline & & & $(.328)$ & $(.479)$ & $(.340)$ & $(.485)$ \\
\hline \multirow[t]{2}{*}{ Wealth Exemption } & & & & & $* .029$ & $* .033$ \\
\hline & & & & & $(.016)$ & $(.019)$ \\
\hline \multirow[t]{2}{*}{ Years of College } & & & & & .075 & .001 \\
\hline & & & & & $(.097)$ & $(.158)$ \\
\hline \multirow[t]{2}{*}{ Age at Draft } & & & & & $* *_{-} .207$ & $*_{-} .198$ \\
\hline & & & & & $(.077)$ & $(.112)$ \\
\hline \multirow[t]{2}{*}{ Point Guard } & & & & & -.062 & .132 \\
\hline & & & & & $(.188)$ & $(.217)$ \\
\hline Obs. & 188 & 138 & 138 & 148 & 171 & 138 \\
\hline $\mathrm{R}^{2}$ & .07 & .12 & .07 & .12 & .14 & .18 \\
\hline
\end{tabular}


Table 5: Logit Model with Dep. Var.=1 if Broke (Odds Ratios)

\begin{tabular}{|c|c|c|c|c|c|c|}
\hline & (1) & (2) & (3) & (4) IV & (5) IV & (6) IV \\
\hline $\begin{array}{l}\text { Investment Effort } \\
\# \text { of Businesses }\end{array}$ & $\begin{array}{l}* * * 4.261 \\
(1.966)\end{array}$ & $\begin{array}{l}* * * 3.54 \\
(1.26)\end{array}$ & $\begin{array}{l}* * * 3.33 \\
(.772)\end{array}$ & $\begin{array}{l}.975 \\
(2.42)\end{array}$ & $\begin{array}{l}.500 \\
(1.141)\end{array}$ & $\begin{array}{c}.349 \\
(.365)\end{array}$ \\
\hline $\begin{array}{l}\text { Confidence } \\
\text { (3-Point Tries) }\end{array}$ & $\begin{array}{l}.808 \\
(.186)\end{array}$ & $\begin{array}{l}.781 \\
(.249)\end{array}$ & $\begin{array}{l}.698 \\
(.393)\end{array}$ & $\begin{array}{l}.801 \\
(.254) \\
\end{array}$ & $\begin{array}{l}.833 \\
(.304) \\
\end{array}$ & $\begin{array}{c}.833 \\
(.307)\end{array}$ \\
\hline $\begin{array}{c}\text { Confidence }^{2} \\
(3-\text { Point Tries }\end{array}$ & $\begin{array}{l}* * 1.196 \\
(.056)\end{array}$ & $\begin{array}{l}* * * 1.256 \\
(.073)\end{array}$ & $\begin{array}{l}* * * 1.240 \\
(.089)\end{array}$ & $\begin{array}{l}* * * 1.264 \\
(.087)\end{array}$ & $\begin{array}{l}* * * 1.265 \\
(.044)\end{array}$ & $\begin{array}{c}* * 1.263 \\
(.053)\end{array}$ \\
\hline 3-Point Success & $\begin{array}{l}.229 \\
(.355) \\
\end{array}$ & $\begin{array}{l}.017 \\
(.019) \\
\end{array}$ & $\begin{array}{l}.011 \\
(.042)\end{array}$ & $\begin{array}{l}.012 \\
(.084) \\
\end{array}$ & $\begin{array}{l}.007 \\
(.056) \\
\end{array}$ & $\begin{array}{l}.007 \\
(.055) \\
\end{array}$ \\
\hline Wealth Exemption & & $\begin{array}{c}* * 1.273 \\
(.136)\end{array}$ & $\begin{array}{r}* * 1.312 \\
(.134)\end{array}$ & $\begin{array}{l}* 1.326 \\
(.223)\end{array}$ & $\begin{array}{c}* * 1.364 \\
(.213)\end{array}$ & $\begin{array}{l}* 1.386 \\
(.247)\end{array}$ \\
\hline Years of College & & & $\begin{array}{r}.828 \\
(1.38) \\
\end{array}$ & & $\begin{array}{c}.421 \\
(.410) \\
\end{array}$ & $\begin{array}{c}.467 \\
(.759)\end{array}$ \\
\hline Age at Draft & & & $\begin{array}{l}1.290 \\
(.914) \\
\end{array}$ & & & $\begin{array}{r}.861 \\
(.900) \\
\end{array}$ \\
\hline Point Guard & & & $\begin{array}{c}1.668 \\
(1.743)\end{array}$ & & & $\begin{array}{c}1.199 \\
(1.467)\end{array}$ \\
\hline Obs. & 138 & 138 & 138 & 138 & 138 & 138 \\
\hline Pseudo $R^{2}$ & .54 & .57 & .58 & .57 & .58 & .58 \\
\hline
\end{tabular}

\section{Alternative Specifications and Hypotheses}

It is a reasonable critique that earnings could play a role. At the same time, it is also possible that earnings are not exogenous and could introduce bias. To deal with this, I use the rookie year salary. As mentioned above, not all NBA players make millions of 
dollars. That said, the average rookie year salary is 1.03 million, while the median is $\$ 800,000$. Table 6 shows no relationship between rookie year salary and investment effort. Furthermore, rookie year salary does not appear to increase the odds of bankruptcy with any statistical significance.

One objection to the 3-point attempts measure is that it is not capturing confidence, but some type of ability, despite the other controls. For this reason, I also test whether 2-point attempts have the same effect. After all, 2-point shots are more the "staple" shot in basketball and a good measure of ability. Using the number of 2-point shots per 36 minutes and controlling for the success in 2-point shots has no impact on investment effort nor on bankruptcy. Thus, it is not likely that this is a story about ability. Tables 6 and 7 show these results.

\section{Table 6: Dep. Var.: Number of For Profit Businesses (OLS)}

\begin{tabular}{|c|c|c|c|c|}
\hline & (1) & $(2)$ & (3) & $(4)$ \\
\hline 2-Point Tries & $\begin{array}{c}.028 \\
(.023)\end{array}$ & $\begin{array}{l}.036 \\
(.027)\end{array}$ & & \\
\hline 2-Point Success & & $\begin{array}{l}.021 \\
(.018)\end{array}$ & & \\
\hline $\begin{array}{c}\text { Rookie Salary } \\
\text { (in millions) }\end{array}$ & & & $\begin{array}{c}.175 \\
(.125) \\
\end{array}$ & $\begin{array}{r}.115 \\
(.144) \\
\end{array}$ \\
\hline Controls & $\mathrm{No}$ & Yes & No & Yes \\
\hline Obs. & 188 & 171 & 180 & 165 \\
\hline $\mathrm{R}^{2}$ & .03 & .13 & .02 & .17 \\
\hline
\end{tabular}


Table 7: Logit Model with Dep. Var.=1 if Broke (Odds Ratios)

\begin{tabular}{|c|c|c|c|c|c|c|}
\hline & (1) & $(2)$ & (3) IV & (4) & (5) & (6) IV \\
\hline 2-Point Tries & $\begin{array}{l}1.109 \\
(.072)\end{array}$ & $\begin{array}{l}1.184 \\
(.167) \\
\end{array}$ & $\begin{array}{l}1.205 \\
(.190) \\
\end{array}$ & & & \\
\hline 2-Point Success & & $\begin{array}{l}1.106 \\
(.074)\end{array}$ & $\begin{array}{l}1.132 \\
(.091)\end{array}$ & & & \\
\hline $\begin{array}{c}\text { Rookie Salary } \\
\text { (in Millions) }\end{array}$ & & & & $\begin{array}{c}2.015 \\
(1.166)\end{array}$ & $\begin{array}{r}.529 \\
(.646) \\
\end{array}$ & $\begin{array}{c}.485 \\
(.617)\end{array}$ \\
\hline Controls & No & Yes & Yes & No & Yes & Yes \\
\hline Obs. & 188 & 171 & 171 & 180 & 165 & 165 \\
\hline Pseudo $\mathrm{R}^{2}$ & .06 & .44 & .45 & .07 & .64 & .65 \\
\hline
\end{tabular}

\section{Conclusion}

This paper has incorporated behavioral phenomena into two standard economic questions: why start a business and how does one succeed. With the data collected on observed behavior, I am able to analyze self-confidence without the bias of self-reporting. Self-confidence makes a diffference in entrepreneurial activity and financial success. In addition, starting businesses actually does help financial solvency, but it often appears to be the opposite because of endogeneity.

\section{References}

1. Baumol, William J. Entrepreneurship: Productive, Unproductive, and Destructive. JPE vol 98: 5, 893-921 
2. Benabou, R., and J. Tirole, "Self-Confidence: Intrapersonal Strategies," IDEI mimeo, June 1999.

3. Benabou, Roland and Tirole, Jean. Self-Confidence and Personal Motivation. QJE. Aug 2002.

4. Brocas, I., and J. Carrillo, "Entry Mistakes, Entrepreneurial Boldness and Optimism," ULB-ECARE mimeo, June 1999.

5. Evans, David S., and Jovanovic, Boyan. "An Estimated Model of Entrepreneurial Choice under Liquidity Constraints." Journal of Political Economy 97 (1989): 80827.

6. Evans, David S., and Leighton, Linda S. "Some Empirical Aspects of Entrepreneurship."American Economic Review 79 (1989): 519-35.

7. Fan, Wei and White, Michelle J. Personal Bankruptcy and the Level of Entrepreneurial Activity. 2011

8. Gropp, Scholz, and White. Personal Bankruptcy and Credit Supply and Demand. QJE. Feb 1997.

9. Hamilton, Barton H. "Does Entrepreneurship Pay? An Empirical Analysis of the Returns to Self-Employment." Journal of Political Economy 108 (2000): 604-31.

10. Holtz-Eakin, Douglas; Joulfaian, David; and Rosen, Harvey S. "Sticking It Out: Entrepreneurial Survival and Liquidity Constraints." Journal of Political Economy 102 (1994): 53-75.

11. Kihlstrom, Richard E., and Laffont, Jean-Jacques. "A General Equilibrium Entrepreneurial Theory of Firm Formation Based on Risk Aversion." Journal of Political Economy 87 (1979): 719-48. 
12. Koszegi, B., "Self-Image and Economic Behavior," MIT, mimeo, October 1999.

13. Weinberg, B., "A Model of OverconŽdence," Ohio State University, mimeo, August1999.

14. Weinstein, N., "Unrealistic Optimism about Future Life Events," Journal of Personality and Psychology, XXXIX (1980), 806-820.

15. White, Michelle J. "Why It Pays to File for Bankruptcy: A Critical Look at Incentives under U.S. Bankruptcy Law and a Proposal for Change." University of Chicago Law Review 65 (1998): 685-732.

16. Zuckerman,M., "Attribution of Success and Failure Revisited, or the Motivational Bias Is Alive and Well in Attribution Theory," Journal of Personality, XLVII (1979), $245-287$. 